\title{
Acetone Removal and Bioelectricity Generation in Dual Chamber Microbial Fuel Cell
}

\author{
${ }^{1}$ Mostafa Rahimnejad, ${ }^{2}$ Mostafa Ghasemi, \\ ${ }^{2}$ Ghasem Najafpour, ${ }^{1}$ Ali Ghoreyshi, ${ }^{1}$ Gholamreza Bakeri, \\ ${ }^{3}$ Seyed Karim Hassani Nejad and ${ }^{1}$ Farid Talebnia
${ }^{1}$ Department of Biochemical Engineering, Chemical Engineering, Babol Noshirvani University, Babol, Iran ${ }^{2}$ Fuel Cell Institute, Chemical Engineering, University Kebangsaan Malaysia, Kebangsaan, Malaysia ${ }^{3}$ Department of Chemistry, Faculty of Science, Babol University of Technology, Babol, Iran

Received 2012-09-25, Revised 2012-10-15; Accepted 2012-10-27

\begin{abstract}
Synthetic waste water contain organic compound can be oxidized in an anaerobic conditions in microbial fuel cell while biodegradation of Chemical Oxygen Demand (COD) takes place under anaerobic condition in anode compartment. The microorganisms for biological treatment of the organic matter were obtained from a UASFB bioreactor. In the treatment of waste water, ones COD was removed the current and power was generated and record. Also polarization curve was obtained. In cathode compartment ferocynide and potassium permanganate with several concentration were add for enhancement of proton oxidation. The performance of MFC for maximum current and power generation were obtained with $300 \mu \mathrm{M} \mathrm{L}^{-1}$ potassium permanganate as oxidizers agent. Maximum generated power and current densities were 22 $\mathrm{mW} / \mathrm{m}^{2}$ and $70 \mathrm{~mA} / \mathrm{m}^{2}$, respectively. Active microorganisms used acetone as electron donors and COD removal was $69 \%$ at the end of process.
\end{abstract}

Keywords: Potassium Permanganate, COD Removal, Bioelectricity, Microbial Fuel Cell

\section{INTRODUCTION}

Production of renewable energy is essential requirements for sustainable human society. Traditional source of energy has several disadvantages such as: Reduction of fossil fuels sources, global warming, energy supply security and risk (Min et al., 2012). Active microorganisms can produce bioelectricity from renewable sources (Pant et al., 2010; Wang et al., 2012).

The relation between metabolic processes and electricity in living organisms first was demonstrated more than 200 years ago by Luigi Galvani. In 1910, Potter discovered electricity generating by active microorganisms such as Escherichia coli and Saccharomyces (Hall and Denning, 1994). Because of energy crisis in recently years, researchers increased their research in this area and developed Microbial Fuel Cell (MFC) (Liu et al., 2012; Nimje et al., 2012; Rahimnejad et al., 2012).

MFC is a bioreactor that converts chemical energy of organic compounds to bioelectrical energy through catalytic reactions of microorganisms under anaerobic conditions (Cha et al., 2010; Rezaei et al., 2009). In recent years MFCs were interested as a way of generating bioelectrical power or hydrogen from biomass without any carbon emission into the environment (Daniel et al., 2009). MFCs are also capable of waste water treatment with simultaneous production of energy. The MFC structure consists of an anode, a cathode and sometimes a membrane or separator between the (Mohan et al., 2008). In recent decades Different kinds of materials have been used as the anode, Corresponding Author: Mostafa Rahimnejad, Department of Biochemical Engineering, Chemical Engineering, Babol Noshirvani University, Babol, Iran 
including plain graphite, carbon cloth, graphite foam, graphite granules and high surface area graphite fiber brush electrodes (Chaudhuri and Lovley, 2003; Fan et al., 2007; He and Angenent, 2006). Cation Exchange Membranes (CEMs), Anion Exchange Membranes (AEMs) and ultra-filtration membranes (Kim et al., 2007; Rozendal et al., 2006) are common separators between the electrodes. Since the cathode is usually a limiting factor in power production in of an MFC (Rismani-Yazdi et al., 2008), various electron accepters, such as ferricyanide and permanganate (He and Angenent, 2006; Rabaey et al., 2004; You et al., 2006), have been used as catholytes in two-chamber MFCs, to enhance performance of the cathodic compartment. Oxygen for its high thermodynamic redox potential, good selfsustaining operation and availability (He and Angenent, 2006), commonly used as an electron accepter. Last researches showed that different wastewaters can be used as substrate and also inoculums for MFCs, to lead energy production from an abundant and inexpensive source. Most of the energy available from the oxidation of the organic load was converted to electricity while the remaining energy was used for microbial growth (Aldrovandi et al., 2009; Du et al., 2007; Wen et al., 2009). Currently wastewater MFCs are being considered as a renewable energy strategy (Wen et al., 2009). In this experiment, the performance of a two chambered MFC with synthetic wastewater as substrate was studied. The influences of different mediator, oxidizer and rate of aeration on voltage, power density and COD removal efficiency of MFC were investigated.

\section{MATERIALS AND METHODS}

Activated sludge was supplied from a UASFB bioreactor. The microorganisms were grown in an anaerobic jar vessel. The medium prepared for seed culture consisted of acetone, yeast extract, $\mathrm{NH}_{4} \mathrm{Cl}$, $\mathrm{NaH}_{2} \mathrm{PO}_{4}, \mathrm{MgSO}_{4}$ and $\mathrm{MnSo}_{4}: 3,3,0.2,0.6,0.2$ and 0.05 $\mathrm{g} \mathrm{L}^{-1}$, respectively.

The medium $\mathrm{pH}$ was initially adjusted to 6.5 and the inoculums were introduced into the media at ambient temperature. The inoculated cultures were incubated at $30^{\circ} \mathrm{C}$. The bacteria were fully grown for the duration of $24 \mathrm{~h}$ in $100 \mathrm{~mL}$ flux without any agitation.

All chemicals and reagents used for the experiments were analytical grades and supplied by Merck (Germany). The pH meter, HANA 211(Romania) model glass-electrode was employed for measuring $\mathrm{pH}$ values of the aqueous phase. The initial $\mathrm{pH}$ of the working solutions was adjusted by addition of diluted $\mathrm{HNO}_{3}$ or $0.1 \mathrm{M} \mathrm{NaOH}$ solutions.

The fabricated cells in the laboratory scale were made of glass (Pyrex) material. The volume of each chamber (anode and cathode chambers) was $650 \mathrm{~mL}$ with working volume of $500 \mathrm{~mL}$. The sample port was provided for the anode chamber, wire point inputs and inlet port. The selected electrodes in MFC were graphite in size of $30 \times 50 \times 1.5 \mathrm{~mm}$. Proton Exchange Membrane (PEM; NAFION 117, Sigma-Aldrich) was used to separate the two compartments. The Nafion area separated the chambers was $9 \mathrm{~cm}^{2}$. Nafion proton exchange membrane was subjected to a course of pretreatment to take off any impurities that was boiling the film for $1 \mathrm{~h}$ in $3 \% \mathrm{H}_{2} \mathrm{O}_{2}$, washed with deionized water, $0.5 \mathrm{M} \mathrm{H}_{2} \mathrm{SO}_{4}$ and then washed with deionized water. The anode and cathode compartments were filled by deionized water when the biological fuel cell was not in use to maintain membrane for good conductivity. Neutral Red (NR), ferricyanide and permanganate were supplied by Merck (Germany).
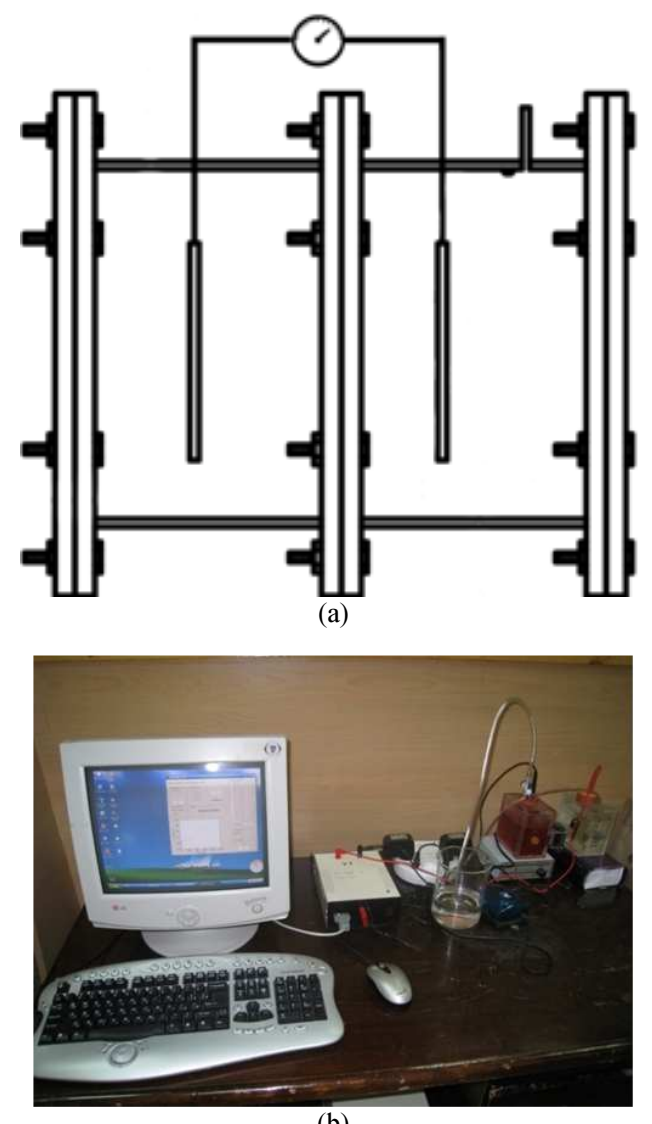

Fig. 1. (a) Schematic drawing (b) Photograph image of MFC and online registered data 
These chemicals with low concentrations (100-500 $\mu \mathrm{mol}$ $\mathrm{L}^{-1}$ were used as mediators in anode and cathode chamber. The schematic diagram of MFC is presented in Fig. 1a. Also, Fig 1 b shows photograph diagram and auxiliary equipment of the fabricated MFC cell.

Scanning Electron Microscopy image (SEM) from the surface of anode electrode was prepared to observe anode surface. The gold layer coated sample were scanned with an electronic microscope (Phillips XL30, Holland). Finally, images of the samples were taken under SEM at magnifications of 2000.

\section{RESULTS}

The performance of the microbial fuel cell was evaluated by the polarization curve. Polarization behavior of this cell was recorded for several external resistances for determination of maximum power generation. Figure 2 shows polarization curve of the fabricated cell without any electron shuttle, after 4 days inoculation. Maximum power and current density were $5.99 \mathrm{~mW} / \mathrm{m}^{2}$ and $21.22 \mathrm{~mA} / \mathrm{m}^{2}$, respectively.

To enhance electrons transferring to electrode, $100 \mu \mathrm{M}$ ferricyanide was added as an oxidizer to cathode compartment. Table 1 shows, maximum power increased to $10.89 \mathrm{~mW} . \mathrm{m}^{-2}$ and maximum current density to $60 \mathrm{~mA} / \mathrm{m}^{2}$.

Permanganate was added to cathode compartment in $100,200,300$ and $400 \mu \mathrm{M}$ concentrations. Figure 3 shows the maximum current and power was obtained at permanganate concentration of $300 \mu \mathrm{M}$. The maximum power and current generated were $22 \mathrm{~mW} \cdot \mathrm{m}^{-2}$ and $70 \mathrm{~mA} \cdot \mathrm{m}^{-2}$, respectively. At any concentration greater than the optimum permanganate concentration $(300 \mu \mathrm{M})$ had no positive impact for additional current and power generation (Fig. 3).

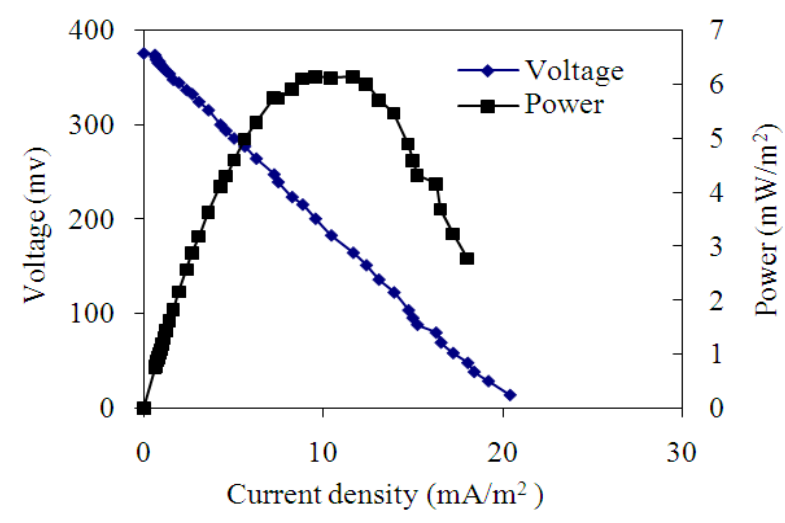

Fig. 2. Polarization curve and power density verse current density at steady state condition with $3 \mathrm{~g} \mathrm{~L}^{-1}$ acetone as electron donors

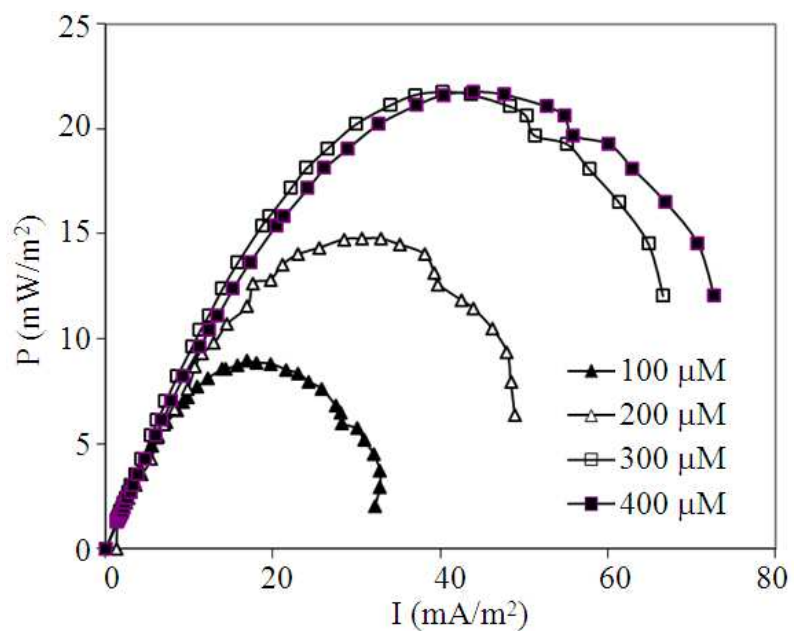

Fig. 3. Effect of permanganate concentration on produced power and voltage 


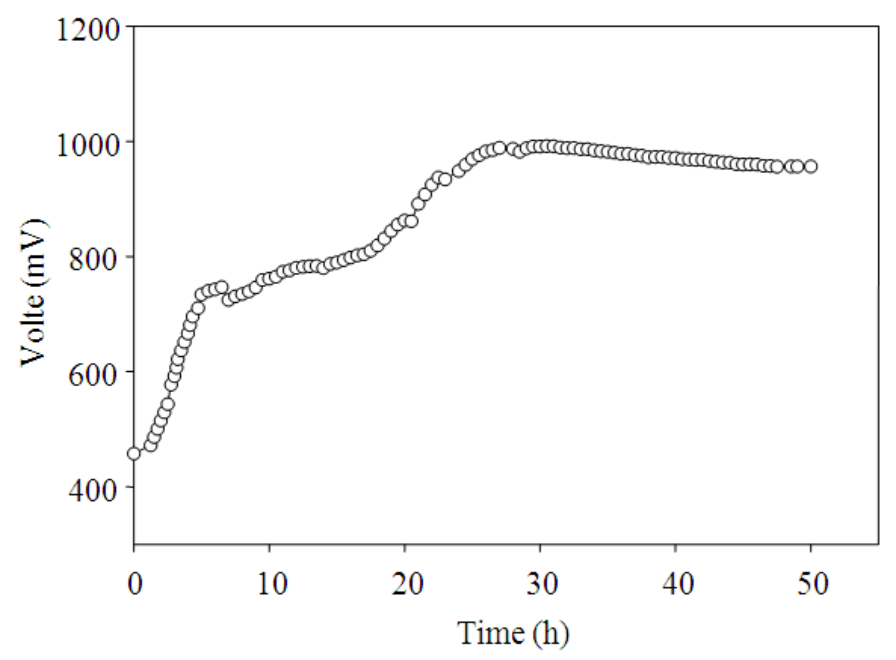

Fig. 4. Produced voltage at optimum condition

Table 1. Effect of ferricyanide concentration on polarization curve

\begin{tabular}{llcc}
\hline $\begin{array}{l}\text { Concentration } \\
(\mu \mathrm{M} / \mathrm{L})\end{array}$ & $\mathrm{OCV}(\mathrm{mV})$ & $\begin{array}{l}\text { Maximum P } \\
\left(\mathrm{mA} / \mathrm{m}^{2}\right)\end{array}$ & $\begin{array}{l}\text { Maximum I } \\
\left(\mathrm{mA} / \mathrm{m}^{2}\right)\end{array}$ \\
\hline 0 & 398 & 5.99 & 21.22 \\
100 & 580 & 10.89 & 30.80 \\
200 & 610 & 12.50 & 45.30 \\
300 & 648 & 15.40 & 52.00 \\
400 & 690 & 18.90 & 58.60 \\
500 & 697 & 19.10 & 60.00 \\
\hline
\end{tabular}

Table 2. Effect of mediators in anode chamber of MFC

\begin{tabular}{lllr}
\hline $\begin{array}{l}\text { NR concentration } \\
(\mu \mathrm{M} / \mathrm{L})\end{array}$ & $\begin{array}{l}\text { OCV } \\
(\mathrm{mV})\end{array}$ & $\begin{array}{l}\text { Maximum P } \\
\left(\mathrm{mA} / \mathrm{m}^{2}\right)\end{array}$ & $\begin{array}{l}\text { Maximum I } \\
\left(\mathrm{mA} / \mathrm{m}^{2}\right)\end{array}$ \\
\hline 0 & 1001 & 22.0 & 70.0 \\
100 & 1001 & 22.2 & 71.2 \\
200 & 908 & 21.3 & 68.8 \\
\hline
\end{tabular}

NR was selected and added to anode chamber as mediator with 100 and $200 \mu \mathrm{M} / 1$ concentrations. Table 2 shows adding electron shuttle in anode chamber had no any effect on produced power and current.

After anode inoculation with mixed culture of microorganisms, the system voltage was registerd by onlie data logger. The fabricated MFC produced stable and repeatable voltage within $50 \mathrm{~h}$ of inoculation, as shown in Fig. 4. The initial voltage was $410 \mathrm{mV}$ and then the voltage was gradually increased. After $27 \mathrm{~h}$ of operation time, The OCV was reached to a maximum value of $1001 \mathrm{mV}$ and it was stabled for the duration of $50 \mathrm{~h}$.
SEM technique was applied to provide surface and morphological information of the anode electrode in anode compartment. A piece of the used anode $(1 \times 1 \mathrm{~cm})$ was investigated by SEM. The taken SEM image is peresented in Fig. 5.

\section{DISCUSSION}

MFCs appear as one kind of a new possibility for the treatment of organic wastes. Acetone is one of the organic compounds which are widely produced in number of chemical industries. Acetone compounds are high-priority toxic chemicals and listed as highly pollutants (Zare et al., 2012). Acetone with initial concentration of $3 \mathrm{~g} \mathrm{~L}^{-1}$ was used as synthetic waste and electron donors in anode compartment. After incubation anode chamber by active microorganisms the produced power was too low. Produced power gradually increased and reached to steady power. The system was reached to steady state condition after $27 \mathrm{~h}$ and the polarization test was taken.

Several concentration $\left(200,300,400\right.$ and $\left.500 \mu \mathrm{M} \mathrm{L}^{-1}\right)$ of ferricyanide were supplemented to obtained optimum concentration of ferricyanide. Maximum current and power was obtained at $400 \mu \mathrm{M}$ concentration in cathode chamber.

Permanganate is another oxidizer which we investigated its effect on our MFC. Discharging the cathode content after ferricyanide tests, Dionized water was added to cathode, to consider the effect of last changes on MFC, the polarization curve of the new content of cathode incereased the performances of fabricated MFC (Fig. 3). 


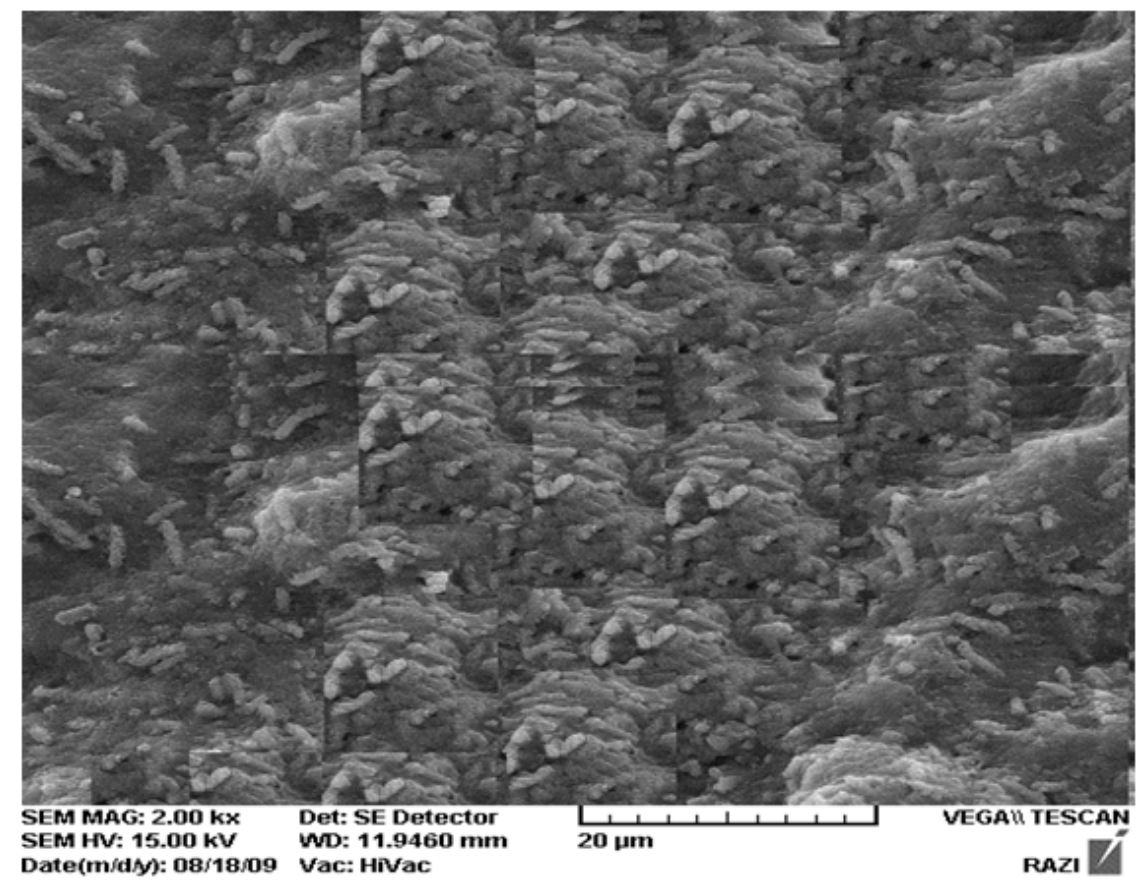

Fig. 5. Scanning electron microscopy image from outer surface of anode electrode.

Electron mediators are used to shuttle produced electrons from the broth to anode surface (Najafpour et al., 2011).

Mediators are artificial compounds and also some of microorganisms can produce it in media. In this case mediators did not have any effect on produced power and current.

One new promising technology for treatment of wastewater is the application of MFC. Active microorganisms grow under anoxic conditions, which can used waste material as substrate and produce bioelectricity. Acetone was used as electron donors in anode compartment. Concentration of waste water in anode chamber was measured by COD. Acetone removal was $69 \%$ at the end of process.

The obtained SEM image from the anode electrode (Fig. 5) shows that surface of electrode was fully covered by several kinds of active microorganisms which were responsible for transfer of produced electrons and thus current generation in the MFC.

\section{CONCLUSION}

The use of microorganisms as biocatalyst is an interesting point in MFCs. The MFC is one of new source for production of energy and waste water treatment simultaneously. The progress of a biological system able to produce bioelectricity from wastewater. The present research demonstrates activated sludge has the ability to generate power from waste water. Aeration in cathode and use of optimum permanganate concentration had enhanced the MFC performances. When the initial permanganate concentration was 300 $\mu \mathrm{M}$, the maximum generated current was $70 \mathrm{~mA} / \mathrm{m}^{2}$. NR as mediators and different concentration of mediators did not have any effect on produced power.

\section{ACKNOWLEDGMENT}

The reachers wish to acknowledge Biotechnology Research Center, Babol Noshirvani University of Technology, Babol, Iran for the facilities provided to accomplish this research.

\section{REFERENCES}

Aldrovandi, A., E. Marsili, L. Stante, P. Paganin and S. Tabacchioniand et al., 2009. Sustainable power production in a membrane-less and mediator-less synthetic wastewater microbial fuel cell. Bioresou. Technol., 100: 3252-3260. DOI: 10.1016/j.biortech.2009.01.041 
Cha, J., S. Choi, H. Yu, H. Kim and C. Kim, 2010. Directly applicable microbial fuel cells in aeration tank for wastewater treatment. Bioelectrochemistry, 78: 72-79. DOI: 10.1016/j.bioelechem.2009.07.009

Chaudhuri, S.K. and D.R. Lovley, 2003. Electricity generation by direct oxidation of glucose in mediatorless microbial fuel cells. Nat. Biotechnol., 21: 1229-1232. DOI: 10.1038/nbt867

Daniel, D.K., B.D. Mankidy, K. Ambarish and R. Manogari, 2009. Construction and operation of a microbial fuel cell for electricity generation from wastewater. Int. J. Hydrogen Energy, 34: 75557560. DOI: $10.1016 /$ j.ijhydene.2009.06.012

$\mathrm{Du}, \mathrm{Z}$., H. Li and T. Gu, 2007. A state of the art review on microbial fuel cells: A promising technology for wastewater treatment and bioenergy. Biotechnol. Advan., 25: 464-482. PMID: 17582720

Fan, Y., H. Hu and H. Liu, 2007. Enhanced Coulombic efficiency and power density of air-cathode microbial fuel cells with an improved cell configuration. J. Power Sour., 171: 348-354. DOI: 10.1016/j.jpowsour.2007.06.220

Hall, L.A. and D. Denning, 1994. Oxygen requirements of Aspergillus species. J. Med. Microbiol., 41: 311315. DOI: 10.1099/00222615-41-5-311

He, Z. and L.T. Angenent, 2006. Application of bacterial biocathodes in microbial fuel cells. Electroanalysis, 18: 2009-2015. DOI: 10.1002/elan.200603628

Kim, J.R., S. Cheng, S.E. Oh and B.E. Logan, 2007. Power generation using different cation, anion and ultrafiltration membranes in microbial fuel cells. Environ. Sci. Technol., 41: 1004-1009. DOI: 10.1021/es062202m

Liu, L., O. Tsyganova, D.J. Lee, A. Su and J.S. Chang, 2012. Anodic biofilm in single-chamber microbial fuel cells cultivated under different temperatures. Int. J. Hydrogen Energy, 37: 15792-15800. DOI: 10.1016/j.ijhydene.2012.03.084

Min, B., F.W. Poulsen, A. Thygesen and I. Angelidaki, 2012. Electric power generation by a submersible microbial fuel cell equipped with a membrane electrode assembly. Bioresou. Technol., 118: 412417. DOI: 10.1016/j.biortech.2012.04.097

Mohan, S.V., G. Mohanakrishna, B.P. Reddy, R. Saravanan and P. Sarma, 2008. Bioelectricity generation from chemical wastewater treatment in mediatorless (anode) Microbial Fuel Cell (MFC) using selectively enriched hydrogen producing mixed culture under acidophilic microenvironment. Biochem. Eng. J., 39: 121-130. DOI: 10.1016/j.bej.2007.08.023
Najafpour, G., M. Rahimnejad and A. Ghoreshi, 2011. The Enhancement of a microbial fuel cell for electrical output using mediators and oxidizing agents. Energy Sou. Part A: Recovery. Utilization Environ. Effects, 33: 2239-2248. DOI: 10.1080/15567036.2010.518223

Nimje, V.R., C.Y. Chen, H.R. Chen, C.C. Chen and Y.M. Huang et al., 2012. Comparative bioelectricity production from various wastewaters in microbial fuel cells using mixed cultures and a pure strain of Shewanella oneidensis. Bioresou. Technol., 104: 315-323. PMID: 22123299

Pant, D., G. Van Bogaert, L. Diels and K. Vanbroekhoven, 2010. A review of the substrates used in Microbial Fuel Cells (MFCs) for sustainable energy production. Bioresou. Technol., 101: 15331543. DOI: 10.1016/j.biortech.2009.10.017

Rabaey, K., N. Boon, S.D. Siciliano, M. Verhaege and W. Verstraete, 2004. Biofuel cells select for microbial consortia that self-mediate electron transfer. Applied Environ. Microbiol., 70: 53735382. DOI: 10.1128/AEM.70.9.5373-5382.2004

Rahimnejad, M., A.A. Ghoreyshi, G.D. Najafpour, H. Younesi and M. Shakeri, 2012. A novel microbial fuel cell stack for continuous production of clean energy. Int. J. Hydrogen Energy, 37: 5992-6000. DOI: $10.1016 /$ j.ijhydene.2011.12.154

Rezaei, F., T.L. Richard and B.E. Logan, 2009. Analysis of chitin particle size on maximum power generation, power longevity and Coulombic efficiency in solid-substrate microbial fuel cells. J. Power Sour., 192: 304-309. DOI: 10.1016/j.jpowsour.2009.03.023

Rismani-Yazdi, H., S.M. Carver, A.D. Christy and O.H. Tuovinen, 2008. Cathodic limitations in microbial fuel cells: An overview. J. Power Sour., 180: 683694. DOI: 10.1016/j.jpowsour.2008.02.074

Rozendal, R.A., H.V.M. Hamelers and C.J.N. Buisman, 2006. Effects of membrane cation transport on $\mathrm{pH}$ and microbial fuel cell performance. Environ. Sci. Technol., 40: 5206-5211. DOI: 10.1021/es060387r

Wang, S., L. Huang, L. Gan, X. Quan and N. Li et al., 2012. Combined effects of enrichment procedure and non-fermentable or fermentable co-substrate on performance and bacterial community for pentachlorophenol degradation in microbial fuel cells. Bioresou. Technol., 120: 120-126. DOI: 10.1016/j.biortech.2012.06.022 
Wen, Q., Y. Wu, D. Cao, L. Zhao and Q. Sun, 2009. Electricity generation and modeling of microbial fuel cell from continuous beer brewery wastewater. Bioresou. Technol., 100: 4171-4175. DOI: 10.1016/j.biortech.2009.02.058

You, S., Q. Zhao, J. Zhang, J. Jiang and S. Zhao, 2006. A microbial fuel cell using permanganate as the cathodic electron acceptor. J. Power Sour., 162: 1409-1415. DOI: 10.1016/j.jpowsour.2006.07.063
Zare, H., G. Najafpour, M. Rahimnejad, A. Tardast and S. Gilani, 2012. Biofiltration of ethyl acetate by Pseudomonas putida immobilized on walnut shell. Bioresou. Technol., 123: 419-423. DOI: 10.1016/j.biortech.2012.07.036 